Pathophysiology

of Haemostasis and Thrombosis
Pathophysiol Haemost Thromb 2005;34:41-47

DOI: $10.1159 / 000088547$
Received: August 26, 2004

Accepted after revision: June 18, 2005

\title{
Inhibition of Thrombin-Induced Vascular Endothelial Growth Factor Production in Human Neuroblastoma (NB-1) Cells by Argatroban
}

\author{
Krishna Pada Sarker ${ }^{a, b}$ Kamal Krishna Biswas ${ }^{a}$ Kazuyo Yamaji ${ }^{a}$ \\ Munekazu Yamakuchi ${ }^{\text {a }}$ Teruto Hashiguchi ${ }^{\text {a }}$ Ki-Young Lee $^{\text {b }}$ \\ Ikuro Maruyama ${ }^{a}$ \\ a Department of Laboratory and Vascular Medicine, Cardiovascular and Respiratory Disorders, Graduate School \\ of Medical and Dental Sciences, Kagoshima University, Kagoshima, Japan; ${ }^{b}$ Department of Cell Biology and \\ Anatomy, Faculty of Medicine, University of Calgary, Calgary, Canada
}

\section{Key Words}

Argatroban $\cdot$ Neuronal cells $\cdot$ Thrombin $\cdot$ Vascular endothelial growth factor

\begin{abstract}
Thrombin, a serine protease that plays a pivotal role in blood coagulation, wound healing, and angiogenesis, has also been implicated in the mitogenesis of various cell types. Previously, we showed that thrombin and the thrombin receptor agonist peptide (TRAP-14; SFLLRNPNDKYEPF) for protease-activated receptor 1 (PAR1) induce vascular endothelial growth factor (VEGF) secretion in PC-12 cells. In this study, we show that thrombin and TRAP-14 also stimulate VEGF secretion in the human NB-1 neuroblastoma cells. In these cells, we further show that thrombin-induced VEGF secretion was blocked by cycloheximide and actinomycin $D$, indicating that de novo protein synthesis is essential for this process. Reduced thrombin-induced VEGF secretion upon treatment with LY294002, calphostin C, or BAPTA, further suggests that the process is dependent on phosphatidyl-inositol-3-kinase, protein kinase $\mathrm{C}$, and calcium. However, the complete loss of thrombin-induced VEGF production upon treatment with argatroban, a derivative of arginine and a potent anticoagulant/antithrombin
\end{abstract}

agent, supports the notion that argatroban serves as a useful therapeutic tool for thrombin-associated pathologic conditions. Here, it appears that argatroban may be effective in controlling disorders linked to thrombin-induced VEGF production in neuronal cells.

Copyright (c) 2005 S. Karger AG, Basel

\section{Introduction}

Thrombin is a multifunctional serine protease, which is generated proteolytically from prothrombin by factor $\mathrm{Xa}$ in the final step of the blood coagulation cascade. Thrombin converts fibrinogen to fibrin, activates platelets and several coagulation factors, and plays a crucial role in thrombosis and hemostasis [1,2]. These cellular effects of thrombin are mediated, at least in part, through the activation of the thrombin receptor that is coupled to $G$ protein. The full name of ' $G$ protein' is GTP-binding protein because in the active state it binds to GTP (guanosine triphosphate). There are two types of $\mathrm{G}$ proteins: heterotrimeric $\mathrm{G}$ proteins and monomeric $\mathrm{G}$ proteins (or small $\mathrm{G}$ proteins). G-protein-coupled receptors are coupled to heterotrimeric $G$ proteins. The heteromeric $G$ protein consists of three subunits: $\alpha, \beta$ and $\gamma$. In the inactive state, the $\alpha$ subunit binds to GDP and the three sub-

\section{KARGER}

Fax +4161306 1234 E-Mail karger@karger.ch www.karger.com
(C) 2005 S. Karger AG, Basel

$1424-8832 / 05 / 0341-0041 \$ 22.00 / 0$

Accessible online at:

www.karger.com/pht
Krishna Pada Sarker

Department of Cell Biology and Anatomy

Faculty of Medicine, University of Calgary

Calgary, AB, T2N 4N1 (Canada)

Tel. +1 4032108583 , Fax +1 403283 8727, E-Mail kpsarker@ucalgary.ca 
units are attached together. When the $\alpha$ subunit binds to GTP, its affinity to the $\beta \gamma$ subunits is decreased, resulting in their dissociation. The separated $\alpha$ and/or $\beta \gamma$ subunits can then interact with their effectors. There are at least three protease-activated receptors (PARs) that have been identified as thrombin receptors, PAR-1, PAR-3, and PAR-4 [3-5]. Like other G-protein-coupled receptors, the three PAR family members consist of a single polypeptide with seven membrane-spanning domains and an extended extracellular N-terminus. However, unlike the receptors for most cellular growth factors, PAR-1 does not require the traditional ligand-receptor complex formation for activation. Instead, the receptor serves as a substrate for proteolytic digestion, yielding an irreversibly activated form on the cell surface to convey additional cell signaling. Thrombin cleaves PAR-1 between Arg41 and Ser42. Cleavage of this site results in a new truncated Nterminus, starting with the amino acid serine-42. The first six to fourteen amino acids (SFLLRNPNDKYEPF) in the newly generated $\mathrm{N}$-terminal domain play a role in intramolecular ligand activation, and have been found to be an agonist for PAR-1 activation [3, 6]. Even in the absence of thrombin, this peptide binds to the second loop of its transmembrane domain, and mimics thrombin activity [7].

Vascular endothelial growth factor (VEGF) is a cytokine encoded by a single gene that generates at least four protein products from alternative splicing of the mRNA: VEGF 121, VEGF 165, VEGF 189, and VEGF 206 [8], the numbers corresponding to the amount of amino acids. It is well documented that VEGF is a potent angiogenic factor and is specific for endothelial cell migration. In addition to tumor angiogenesis [9], enhanced expression of VEGF has also been implicated in rheumatoid arthritis [10], wound healing [11], diabetic retinopathy [12], and atherosclerosis [13], indicating that VEGF may play a critical role in pathophysiological states.

It has been suggested that thrombin generated following injury to the central nervous system disrupts the blood-brain barrier [14], which ensures homeostasis of the brain microenvironment. Similarly, VEGF has been shown to induce the permeability of the blood-brain barrier in vitro and in vivo $[15,16]$.

Argatroban [(2R,4R)-4-methyl-1,2,3,4-tetrahydro-8quinolinesulfonyl]- $L$-arginyl-2-piperidine-carboxylic acid monohydrate] is a derivative of arginine that competitively binds to the active site of thrombin (fig. 1). Argatroban has an anticoagulant effect $[17,18]$, and abrogates thrombus formation in heparin-induced thrombocytopenia with thrombosis syndrome [19]. Recently,

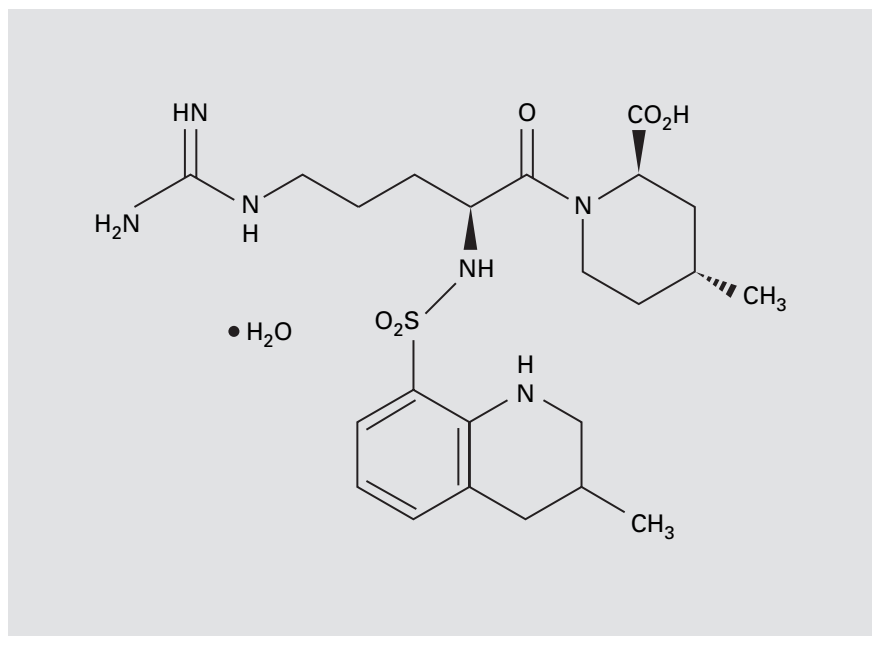

Fig. 1. Chemical structure of argatroban.

argatroban has been approved for clinical use in certain disease conditions. In Japan, argatroban is used for the treatment of chronic peripheral arterial obstructive disease and acute ischemic stroke, and in the United States, it has recently been approved for use in the treatment of thrombosis in patients with heparin-induced thrombocytopenia. Data presented in this study support the concept that argatroban is a useful therapeutic tool for thrombinassociated pathologic conditions, including those in neuronal cells.

\section{Materials and Methods}

\section{Materials}

BAPTA, LY294002, and calphostin C were purchased from Calbiochem (San Diego, Calif., USA). Human thrombin and other chemicals were purchased from Sigma (St. Louis, Mo., USA). Argatroban was kindly provided by Daiichi Pharmaceutical (Tokyo, Japan)

\section{Cell Culture}

Human neuroblastoma (NB-1) cells were maintained in DMEM and RPMI-1640 (1:1) containing 10\% fetal bovine serum with appropriate antibiotics at $37^{\circ} \mathrm{C}$ in a $5 \% \mathrm{CO}_{2}$ atmosphere and $95 \%$ air. Cells used for experiments were exposed to DMEM/RPMI containing $0.2 \%$ FBS for the indicated periods.

\section{ELISA for VEGF}

The VEGF levels in the culture media were measured by a colorimetric ELISA with slight modifications of the chemiluminescence enzyme immunoassay method [20]. Briefly, an anti-VEGF/ VPF IgG was used to coat the ELISA plates. Samples diluted in phosphate-buffered saline containing $1 \%$ BSA were added to the wells and incubated for $1 \mathrm{~h}$ at $22^{\circ} \mathrm{C}$. After washing, a peroxidase 
Fig. 2. Thrombin induces VEGF secretion from NB-1 cells in a dose- and time-dependent manner. a Cells plated onto 12-well dishes $\left(1 \times 10^{5}\right.$ cells/well $)$ were treated with thrombin at different concentrations. VEGF released into the culture media $24 \mathrm{~h}$ after thrombin addition was assayed by ELISA as described in Materials and Methods. b Thrombin $(1 \mathrm{U} / \mathrm{ml})$ was added to NB-1 cells, and VEGF secretion was measured at the indicated time points following thrombin treatment. Values are means \pm SD from three separate experiments.

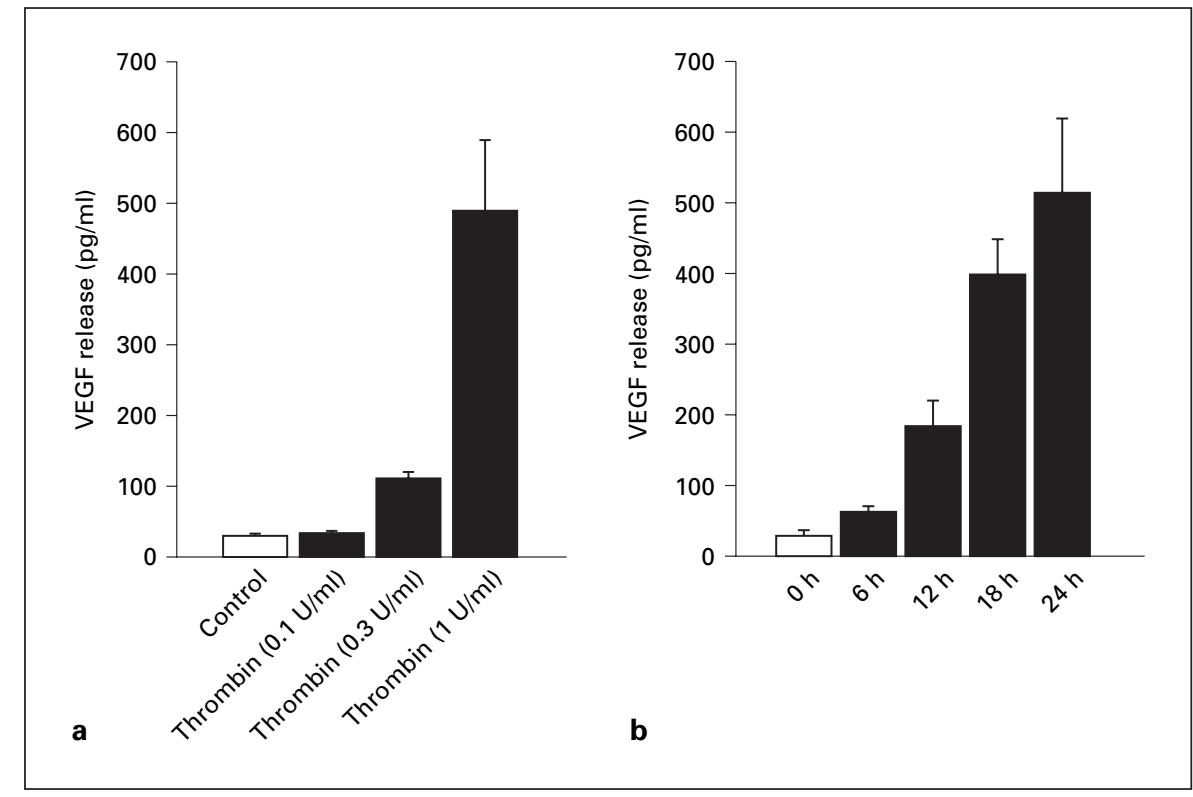

(POD)-conjugated Fab'-fragment of the coating antibody was added, and the samples incubated for another hour at $22^{\circ} \mathrm{C}$. $O$-Phenylene-diamine was used as a reaction substrate. The M-Vmax Microplate reader (Molecular Devices, Mass., USA) was used to detect reactivity.

\section{RT-PCR Analysis}

NB-1 cells were treated with thrombin and the thrombin receptor agonist peptide (TRAP) for the indicated periods. Total RNAs were extracted using an RNA extraction kit, TRIZOL (Gibco, Gaithersburg, Md., USA), and reverse transcription was performed at $42^{\circ} \mathrm{C}$ using reverse transcriptase (Takara, Japan). One twentieth of the volume of the RT product was amplified using Taq DNA polymerase (Promega, Madison, Wisc., USA), following the manufacturer's instructions. The sense primer was 5'-GAGAATTCGGCCTCCGAA-, and the antisense primer was 5'-GAGCATGCCCTCCTGCCC- for VEGF. The PCR profile consisted of a 1 -min initial denaturation at $94^{\circ} \mathrm{C}$, followed by 30 cycles, with each cycle comprising a 1-min denaturing step at $94^{\circ} \mathrm{C}, 1 \mathrm{~min}$ extension at $72^{\circ} \mathrm{C}, 1 \mathrm{~min}$ annealing at $63^{\circ} \mathrm{C}$, and $5 \mathrm{~min}$ extension at $72^{\circ} \mathrm{C}$. The PCR products were analyzed in a $2 \%(\mathrm{w} / \mathrm{v})$ agarose gel.

\section{Results}

To further examine mediation of VEGF secretion by thrombin, we used the human neuroblastoma (NB-1) cells as a model system for our study. Figure 2 a shows that an increase in VEGF release from NB-1 cells occurs upon addition of $0.3 \mathrm{U} / \mathrm{ml}$ thrombin and a further significant increase in VEGF production was observed following the addition of $1 \mathrm{U} / \mathrm{ml}$ thrombin. In figure $2 \mathrm{~b}$, we show that thrombin induced some VEGF release within $6 \mathrm{~h}$ of addition. A more remarkable and increasing VEGF production was noted 12,18 , and $24 \mathrm{~h}$ after thrombin addition. This was followed by a gradual decrease in VEGF release, which reached a plateau $36 \mathrm{~h}$ after thrombin addition (data not shown). Thus, in NB-1 cells, thrombin induced VEGF secretion in a dose- and time-dependent manner.

Since the protease-activated receptors, PAR-1 and PAR-3, which were shown to be present in NB-1 cells by RT-PCR (fig. 3a), have been identified as thrombin receptors [3-5], we examined the possibility that thrombin induces VEGF secretion through PAR activation. TRAP14 (SFLLRNPNDKYEPF) induced VEGF production in a dose- and time-dependent fashion, respectively (fig. 3b, c), indicating that TRAP-14 mimicked the effects of thrombin on VEGF secretion from NB-1 cells.

Next, we sought to determine whether thrombin-induced VEGF production was dependent on protein and RNA syntheses. Figure 4 shows that NB-1 cells treated with the protein synthesis inhibitor, cycloheximide, or the transcription inhibitor, actinomycin $\mathrm{D}$, prior to thrombin addition exhibited considerably reduced VEGF secretion. This result suggests that both protein and RNA syntheses are essential for thrombin-induced VEGF secretion from NB-1 cells.

Activation of the thrombin receptor is known to cause phosphatidyl-inositol-3-kinase (PI3-K) activation, which subsequently leads to an increase in intracellular calcium 
Fig. 3. TRAP-14 mimics the effect of thrombin on VEGF secretion from NB-1 cells. a RT-PCR revealed the expression of PAR-1 (lane 1) and PAR-3 (lane 2) in NB-1 cells. Lane 3 represents the PCR-negative control where double-distilled $\mathrm{H}_{2} \mathrm{O}$ was used instead of cDNA as template. b Increasing concentrations of TRAP-14 resulted in a corresponding increase in VEGF release from NB-1 cells. c Increasing amounts of VEGF secretion were detected up to $24 \mathrm{~h}$ following addition of TRAP-14 $(100 \mu M)$. Values are means \pm SD from three separate experiments.

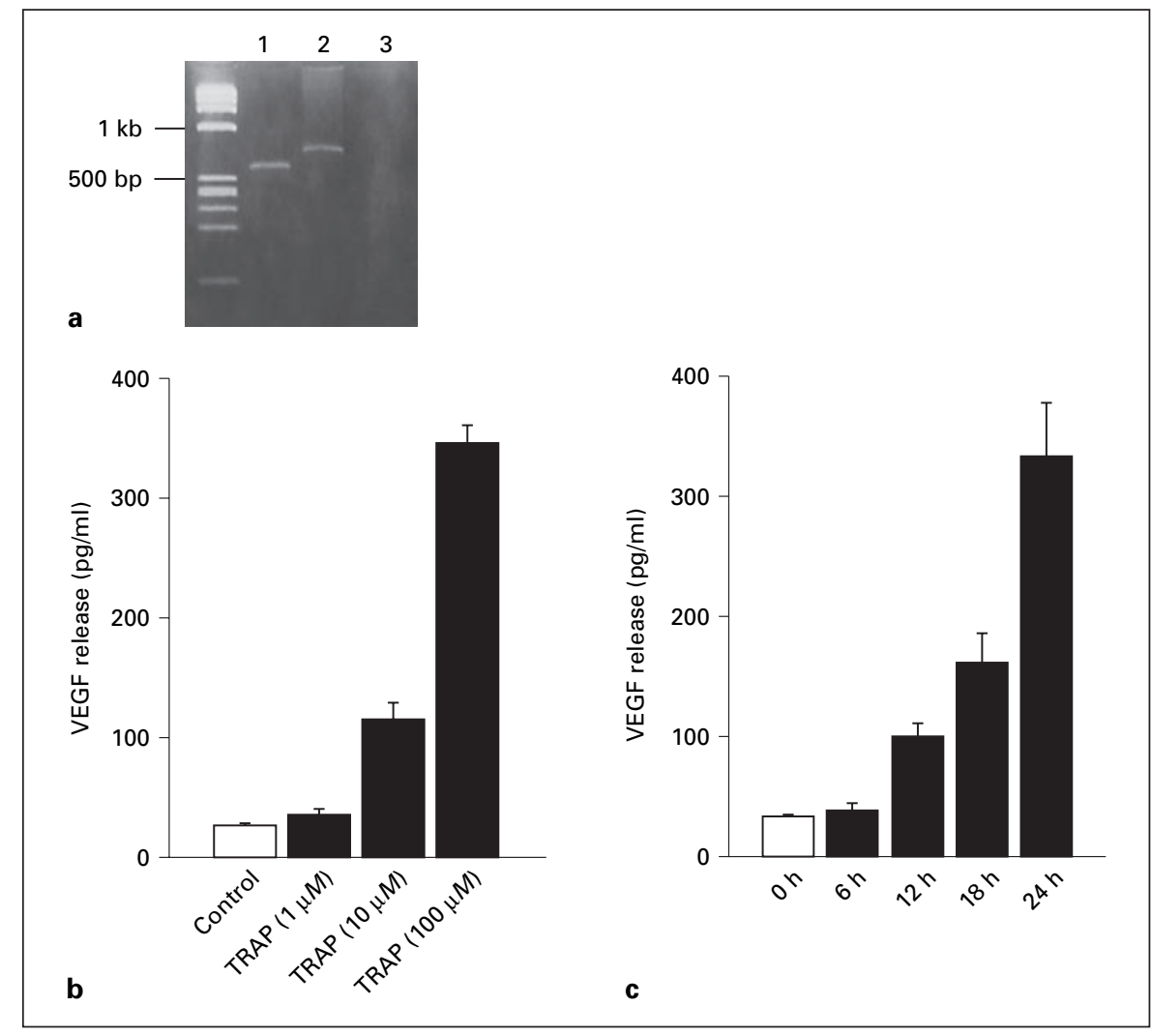

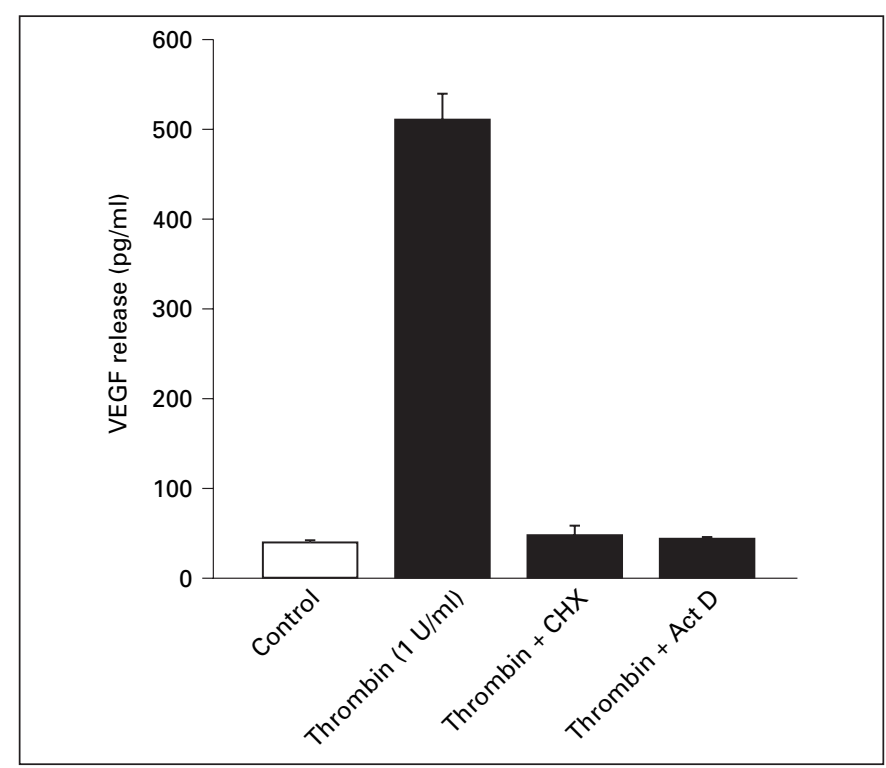

Fig. 4. Cycloheximide and actinomycin $D$ inhibit thrombin-induced VEGF secretion from NB-1 cells. Cells were pretreated with cycloheximide (CHX;1 $1 \mu \mathrm{g} / \mathrm{ml}$ ) and actinomycin D (Act D; $0.1 \mathrm{mg} /$ $\mathrm{ml}$ ) for $30 \mathrm{~min}$ prior to the addition of thrombin $(1 \mathrm{U} / \mathrm{ml})$. VEGF was measured $24 \mathrm{~h}$ after thrombin addition. Values are means \pm $\mathrm{SD}$ from three independent experiments. and protein kinase $\mathrm{C}(\mathrm{PKC})$ activation. In this study, we found that the calcium chelator, BAPTA, the PI3-K inhibitor, LY294002, and the PKC inhibitor, calphostin C, significantly reduced thrombin-induced VEGF secretion from NB-1 cells (fig. 5). The basal level of VEGF secretion has been found to be slightly but nonsignificantly increased compared to control followed by the administration of these pharmacological blockers. This observation is consistent with our previous findings in PC12 cells [21]. We have no explanation for this phenomenon. However, one possible explanation could be that these inhibitors may prevent RNase, which may regulate basal VEGF production, leading to the upregulation of basal VEGF. Thus, it appears that PI3-K, PKC, and calcium participate in the thrombin-stimulated VEGF secretion from NB-1 cells.

Although argatroban is known for blocking thrombin activity, this effect is not well characterized in neuronal cells. Thus, we sought to determine whether argatroban could inhibit thrombin-induced VEGF secretion from NB- 1 cells. Figure 6 shows that increasing concentrations of argatroban resulted in a corresponding decrease in thrombin-induced VEGF secretion from NB-1 cells. At 


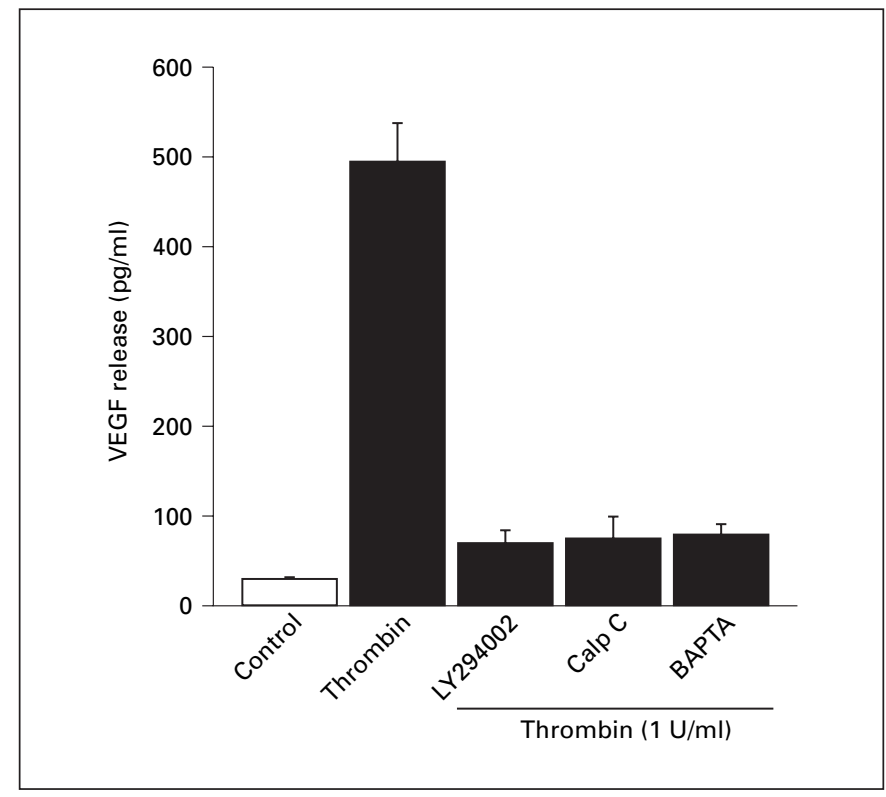

Fig. 5. Thrombin-induced VEGF secretion is dependent on PI3-K, PKC, and intracellular calcium. Cells were pretreated with LY294002 $(10 \mu M)$, calphostin (Calp) C $(1 \mu M)$ or BAPTA $(10 \mu M)$ for $30 \mathrm{~min}$ prior to the addition of thrombin $(1 \mathrm{U} / \mathrm{ml})$. VEGF was measured $24 \mathrm{~h}$ following thrombin addition. Values are means \pm SD of three independent experiments.

$1 \mu M$ argatroban, thrombin-induced VEGF secretion approached basal levels, suggesting that argatroban can completely block the effect of thrombin in neuronal cells.

To determine whether time is crucial to achieve the inhibitory effects of argatroban on thrombin-induced VEGF secretion, NB-1 cells were incubated with argatroban either prior to or following thrombin exposure. As shown in figure 7 , pre-incubation or treatment with argatroban within $10 \mathrm{~min}$ following thrombin addition blocked the stimulation of VEGF secretion by thrombin. A considerable inhibition of VEGF secretion was also observed when argatroban was added $30 \mathrm{~min}$ after thrombin exposure. However, no significant inhibitory effect was noted when argatroban treatment was delayed for $60 \mathrm{~min}$ or more following thrombin exposure.

\section{Discussion}

Thrombin is a well-established mitogen that is generated in the coagulation cascade following tissue injury. Apart from its role in the mitogenic division of various cell types, thrombin has been implicated in wound repair,

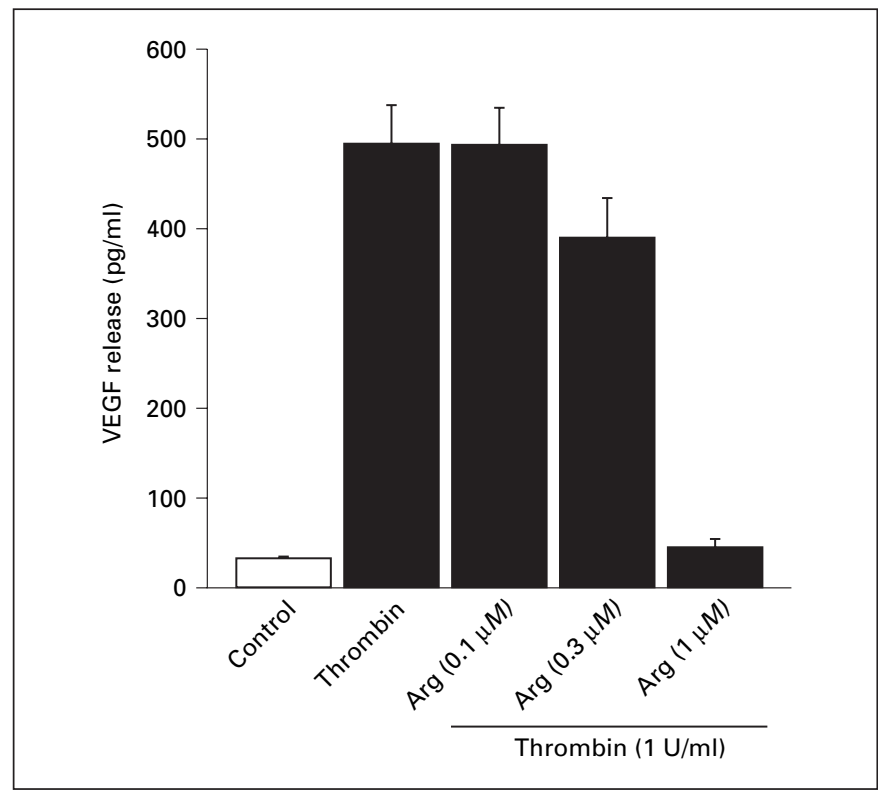

Fig. 6. Argatroban (Arg) inhibits thrombin-induced VEGF secretion. Cells were pretreated with different concentrations of argatroban for $30 \mathrm{~min}$ prior to the addition of thrombin $(1 \mathrm{U} / \mathrm{ml})$. VEGF was measured by ELISA $24 \mathrm{~h}$ after thrombin addition. Values are means $\pm \mathrm{SD}$ of three separate experiments.

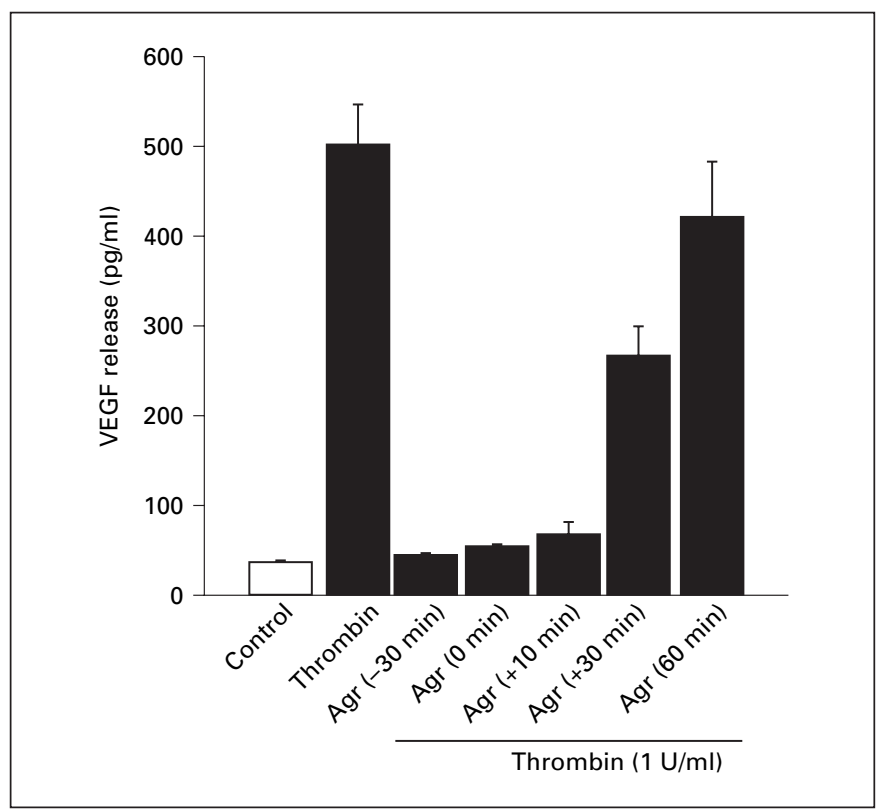

Fig. 7. Timing of argatroban (Arg) treatment is critical for inhibition of thrombin-induced VEGF secretion. NB-1 cells were treated with argatroban $(1 \mu M)$ at various time points before, during, and after exposure to thrombin $(1 \mathrm{U} / \mathrm{ml})$. VEGF was measured $24 \mathrm{~h}$ after thrombin addition. Values are means \pm SD of three independent experiments. 
inflammation, brain edema, and reactive gliosis following CNS injury [14]. Thrombin has also been found to induce the synthesis and secretion of nerve growth factor [22]. In addition, we and others have reported that thrombin induces VEGF production in vascular smooth muscle cells and in PC12 cells [21, 23, 24]. Incidentally, both thrombin and VEGF have been shown to alter the permeability of the blood-brain barrier [14-16]. Furthermore, enhanced VEGF expression has also been observed in tumor angiogenesis [9], rheumatoid arthritis [10], wound healing [11], diabetic retinopathy [12], and atherosclerosis [13]. Thus, it appears that VEGF plays an important role in a number of disease conditions.

In this study, we found that thrombin induces VEGF secretion from NB-1 cells. It is well established that thrombin generally exerts its cellular activities through the cleavage of the PAR-1, PAR-3, or PAR-4 thrombin receptor [3-5]. Since the sequence of TRAP-14, which enhances thrombin-induced VEGF secretion from NB-1 cells, corresponds to the cleavage product from PAR-1 digestion by thrombin, our results imply that thrombin triggered VEGF secretion via PAR-1 activation. This result is consistent with the finding that a high level of TRAP is essential to observe the cellular effects of thrombin $[25,26]$. In contrast, PAR-3, which has been identified as a second thrombin receptor, acts as a cofactor for PAR-4, which is normally expressed in platelets [27]. Moreover, a PAR-3 agonist does not induce VEGF production in NB-1 cells (data not shown).

Thrombin receptor activation can cause membrane phosphatidyl turnover, which results in the generation of phosphatidylinositide and diacylglycerol. The latter two activate PKC in most of the mitogenic signaling pathways. There are several lines of evidence that PI3-K binds to the endoplasmic reticulum, and increases intracellular calcium, resulting in the activation of calcium-dependent kinases, including PKC. Characterization of thrombininduced VEGF secretion from NB-1 cells revealed that activation of PI3-K and PKC, and intracellular calcium, are critical for this process, which requires de novo protein synthesis. Together, our results suggest that PI3-K, $\mathrm{PKC}$ and $\mathrm{Ca}_{2}{ }^{+}$mediate thrombin-induced VEGF release in NB-1 cells.

Reduction in secondary microthrombi and improved regional collateral cerebral blood flow is the proposed mechanism of inhibition of thrombin activity. Argatroban is a direct thrombin inhibitor which binds to the catalytic site of the thrombin molecule. It binds rapidly and reversibly to both clot-bound and soluble thrombin. The relatively short elimination half-life of argatroban (39-
$51 \mathrm{~min}$ ) and its reversible binding allow rapid achievement of therapeutic effect on initiation of therapy and rapid restoration of normal hemostasis upon cessation of therapy [28]. Argatroban given after thrombus formation by intraperitoneal implantation of an osmotic pressure pump was shown to reduce infarct size and neurologic deficits on day 3 and microthrombi generation on day 1 , and to raise the regional cerebral blood flow on day 1 , at a plasma level of $0.2-0.6 \mu M$. Argatroban was considered to exert its effects by salvaging neuronal cells in the ischemic penumbra and suppressing extension of the infarction into the penumbra by keeping blood vessels patent, mainly through the inhibition of microthrombogenesis [29]. Therefore, the concentration of argatroban used in the present study has a potential therapeutic benefit, supporting its clinical usefulness in the treatment of acutephase cerebral thrombosis. However, the role of argatroban in inhibiting the effect of thrombin, particularly in neuronal cells, requires further investigation in order to fully understand its therapeutic potential. Our finding that argatroban blocks thrombin-induced VEGF secretion from NB-1 cells suggests that argatroban may be an effective tool in controlling diseases linked to thrombininduced VEGF production in neuronal cells.

\section{Acknowledgements}

We thank Daiichi Pharmaceutical (Tokyo, Japan) for kindly providing argatroban. We thank Dr. Jesusa L. Rosales for helpful discussion. K.P.S. is an Alberta Cancer Board postdoctoral fellow. This work was supported by a grant from the Ministry of Public Health and Welfare (Kosesho) of Japan. 


\section{References}

1 Fenton JW 2nd: Thrombin. Ann NY Acad Sci 1986;485:5-15.

$\checkmark 2$ Berg DT, Wiley MR, Grineel BW: Enhanced protein $\mathrm{C}$ activation and inhibition of fibrinogen cleavage by a thrombin modulator. Science 1996;273:1389-1391.

-3 Vu TK, Hung DT, Wheaton VI, Coughlin SR: Molecular cloning of functional thrombin receptor reveals a novel proteolytic mechanism of receptor activation. Cell 1991;64:10571068.

$\checkmark 4$ Rasmussen UB, Vouret-Craviari V, Jallat S, Schlesinger Y, Pages G, Pavirani A, Lecocq JP, Pouyssegur J, Van Obberghen-Schilling E: cDNA cloning and expression of a hamster alpha-thrombin receptor coupled to $\mathrm{Ca}^{2+}$ mobilization. FEBS Lett 1991;288:123-128.

$\checkmark 5$ Ishihara H, Connolly AJ, Zeng D, Kahn ML, Zheng YW, Timmons C, Tram T, Coughlin SR: Protease-activated receptor 3 is a second thrombin receptor in humans. Nature 1997; 386:502-506.

6 Nystedt S, Emilsson K, Wahlestedt C, Sundelin $\mathrm{J}$ : Molecular cloning of potential protease activated receptor. Proc Natl Acad of Sci USA 1994;91:9208-9212.

7 Nanevicz T, Ishii M, Wong I, Chen M, Chen J, Turek CW, Cohen FB, Coughlin SR: Mechanisms of thrombin receptor agonist specificity. Chimeric receptors and complementary mutations identify an agonist recognition site. J Biol Chem 1995;270:21619-21625.

$>8$ Charnock-Jones DS, Sharkey AM, Rajput WJ, Burch D, Schofield JP, Fountain SA, Boocock CA, Smith SK: Identification and localization of alternately spliced mRNAs for vascular endothelial growth factor in human uterus and estrogen regulation in endometrial carcinoma cell lines. Biol Reprod 1993;48:1120-1128.

$>9$ Kim KJ, Winer J, Armanini M, Gillett N, Phillips HS, Ferrara N: Inhibition of vascular endothelial growth factor-induced angiogenesis suppresses tumor growth in vivo. Nature 1993; 362:841-844.

10 Brown LF, Yeo KT, Berse B, Yeo TK, Senger DR, Dvorak HF, van de Water L: Expression of vascular permeability factor (vascular endothelial growth factor) by epidermal keratinocytes during wound healing. J Exp Med 1992; 176:1375-1379.
11 Koch AE, Harlow LA, Haines GK, Amento EP, Unemori EN, Wong WL, Pope RM, Ferrara $\mathrm{N}$ : Vascular endothelial growth factor. A cytokine modulating endothelial function in rheumatoid arthritis. J Immunol 1994;152: 4149-4156.

12 Aiello LP, Avery RL, Arrigg PG, Keyt BA, Jampel HD, Shah ST, Pasquale LR, Thieme H, Iwamoto MA, Park JE: Vascular endothelial growth factor in ocular fluid of patients with diabetic retinopathy and other retinal disorders. N Engl J Med 1994;331:1480-1487.

13 Ramos M, Kuzua M, Esaki T, Miura S, Satake $\mathrm{S}$, Asai T, Hayashi T, Iguchi A: Induction of macrophage VEGF in response to oxidized LDL and VEGF accumulation in human atherosclerotic lesions. Arterios Thromb Vasc Biol 1998; 18:1188-1196.

14 Nishino A, Suzuki M, Yoshimoto T, Otani H, Nagura H: A novel aspect of thrombin in the tissue following central nervous system injury. Acta Neurochir 1994;66:86-88.

15 Wang W, Merrill MJ, Borchardt RT: Vascular endothelial growth factor affects permeability of brain microvessel endothelial cells in vitro. Am J Physiol 1996;271:C1973-C1980.

16 Zhang ZG, Zhang L, Jiang Q, Zhang R, Davies K, Powers C, Bruggen N, Chopp M: VEGF enhances angiogenesis and promotes blood-brain barrier leakage in the ischemic brain. J Clin Invest 2000; 106:829-838.

17 Berry CN, Girardot C, Lecoffre C, Lunven C: Effects of the synthetic thrombin inhibitor argatroban on fibrin- or clot-incorporated thrombin: comparison with heparin and recombinant Hirudin. Thromb Haemost 1994; 72 381-386.

-18 Tomaru T, Nakamura F, Miwa AY, Fujimori Y, Omata M, Okada R, Uchida Y: Antithrombin and thrombolytic effects of a new antithrombin agent: angioscopic and angiographic comparison with heparin or batroxobin. J Interv Cardiol 1994;7:409-419.

19 Kobayashi S, Tazaki Y: Effect of the thrombin inhibitor argatroban in acute cerebral thrombosis. Semin Thromb Hemost 1997;23:531534.

20 Hanatani M, Tanaka Y, Kondo S, Ohmori I, Suzuki H: Sensitive chemiluminescence enzyme immunoassay for vascular endothelial growth factor/vascular permeability factor in human serum. Biosci Biotech Biochem 1995; 59:1985-1989.
21 Sarker KP, Yamahata H, Nakata M, Arisato T, Nakajima T, Kitajima I, Maruyama I: Recombinant thrombomodulin inhibits thrombin-induced vascular endothelial cell growth factor (VEGF) in neuronal cells. Haemostasis 1999; 26:343-352.

22 Neveu I, Jehan F, Jandrot-Perrus M, Wion D, Brachet P: Enhancement of the synthesis and secretion of nerve growth factor in primary cultures of glial cells by proteases: a possible involvement of thrombin. J Neurochem 1993; 60:858-867.

23 Arisato T, Sarker KP, Kawahara K, Hashiguchi T, Nakata M, Osame M I, Kitajima I, Maruyama I: The agonist of protease-activated receptor-1 (PAR) but not PAR3 mimics thrombin-induced vascular endothelial growth factor in human smooth muscle cells. Cell Mol Life Sci 2003;60:1716-1724.

24 Bassus S, Herkert O, Kronemann N, Gorlach A, Bremerich D, Kirchmaier CM, Busse R, Schini-Kerth VB: Thrombin causes vascular endothelial growth factor expression in vascular smooth muscle cells: role of reactive oxygen species. Arterioscler Thromb Vasc Biol 2001; 21:1550-1555.

25 Grabham P, Cunningham DD: Thrombin receptor activation stimulates astrocyte proliferation and reversal of stellation by distinct pathways: involvement of tyrosine phosphorylation. J Neurochem 1995;64:583-591.

26 Grand RJ, Grabham PW, Gallimore MJ, Gallimore PH: Modulation of morphological differentiation of human neuroepithelial cells by serine proteases: independence from blood coagulation. EMBO J 1989;8:2209-2215.

$\checkmark 27$ Kahn ML, Zheng YW, Huang W, Bigornia V, Zeng D, Moff S, Farese RV Jr, Tam C, Coughlin SR: A dual thrombin receptor system for platelet activation. Nature 1998;394:690694.

28 McKeage K, Plosker GL: Argatroban. Drugs 2001;61:515-522.

29 Tamao Y, Kikumoto R: Effect of argatroban, a selective thrombin inhibitor, on animal models of cerebral thrombosis. Semin Thromb Hemost 1997;23:523-530. 